\title{
Determinants of the Solvency of Insurance Companies in Palestine
}

\author{
Yousef Abdel Latif Abdel Jawad ${ }^{1} \&$ Issam Ayyash ${ }^{2}$ \\ ${ }^{1}$ Al-Quds Open University, Palestine Territory \\ ${ }^{2}$ Palestine Technical University, Palestine Territory \\ Correspondence: Yousef Abdel Latif Abdel Jawad, Al-Quds Open University, Palestine Territory.
}

Received: July 24, 2019

Accepted: August 23, 2019

Online Published: September 8, 2019

doi:10.5430/ijfr.v10n6p188

URL: https://doi.org/10.5430/ijfr.v10n6p188

\begin{abstract}
The study aimed to investigate the factors that affect the solvency of the insurance companies in Palestine and to highlight the nature and strength of the relationship between liquidity, investment, leverage, claims and the solvency of the insurance companies in Palestine.

To achieve the objectives of the study, the descriptive and quantitative analysis methods were used in the study. Based on the data of the financial statements of seven insurance companies (out of 9 companies) and by using regression of fixed effects of panel data for 2010-2017, the study found that the claims have a positive effect on the financial solvency and leverage has a negative effect on the solvency of insurance companies in Palestine, while investment and liquidity have an insignificant effect on financial solvency.
\end{abstract}

Keywords: solvency, insurance companies, risk, leverage, liquidity, claims

JEL: C23, C40, C51, G22, H32.

\section{Introduction}

The insurance sector is one of the most important economic sectors in the world, and the system of any economy in the world depends on the safety of its financial system, especially the insurance sector because it provides economic protection for the human and material resources of the society.

The main objective of insurance is to compensate and protect individuals and enterprises from likely potential damage caused to them. During the last two decades of the previous century, the insurance sector saw significant development and renaissance in the economic market, particularly the global financial market, affected by the large shift in technology and industry. And with the advent of financial globalization, the growth of financial flows, which have greatly affected the insurance sector and its development, has accelerated.

Insurance began almost in Europe after the First World War and became a vital element in the modern economy, because of the gains and financial well-being of all the economies of developed and developing countries (Pearson, 2015).

According to SIGMA (insurance research, studies, and statistics institution established in 1960 in Switzerland), insurance activities in developed countries were growing faster than in developing countries. This is due to the better spread of the insurance culture in the developed countries, in addition to the high risk of investment projects implemented in the developed countries.

Palestine, like other countries affected by the renaissance and development of the insurance sector despite the weakness of the existing economic system, where the insurance sector in Palestine is newly established. With the coming of the Palestinian Authority in 1994, it became the legal authority to supervise the insurance sector, however, this sector remained suffering from lack of organization and management control over its work and the spread of the culture of insurance at the required level, which left the insurance sector weak and unorganized for nearly ten years, until the establishment of the Capital Market Authority, which became the official legal body authorized to manage the insurance sector, supervision and control (Mas, 2016).

The number of companies operating in the insurance sector in Palestine by the end of 2017 was 9 companies, all of them belonging to the private sector. The insurance sector grew by $18.7 \%$, and the insurance portfolio reached \$255.4 million until the end of 2017, the insurance sector's share of GDP is $2 \%$ for 2017 (PCMA, 2018). 
As insurance companies are the main components of the economic system in Palestine and the safety of the insurance sector from the safety of the economic situation as a whole, it is necessary to study the financial status of these companies and their efficiency in meeting their obligations when they mature, which is called the financial solvency (Daykin.et al, 1984).

The importance of studying the solvency of insurance companies has increased recently, because of the great competition witnessed by the insurance industry, and the management of the company, its shareholders, its employees, and the document holders are keen to continue the business of the company, and enhance its reputation and avoid any risks (Affolter, 2009), in addition to the attention of regulators to the financial situation of insurance companies. The need arose to answer the following question: What factors affect the solvency of insurance companies in Palestine, and what is the nature and strength of the relationship between these factors and solvency?

\section{Literature Review}

Several studies have examined the determinants of the solvency of insurance companies, Economic and private factors affecting the solvency of insurance companies were studied.

In a study (Shiu, 2005), the solvency determinants were examined, including economic and business factors in the UK life insurance market, and by using panel data for the period 1986-1999, the study found that solvency positively correlated with asset-to-bond ratio and positively to equity-to-asset ratio, while solvency is negatively correlated with unexpected inflation, market competition, and pension reserves to total reserves, company size, and leverage.

In a similar study of insurance companies in the UK, (Caporale et.al., 2017) analyzed the insolvency risk of insurance companies, using data from 515 companies for 30 years, the study showed that macroeconomic factors including interest rates, real exchange rate, and foreign direct investment are necessary to assess the credit risk of insurance companies, while corporate factors such as underwriting, leverage, liquidity, reinsurance, and organizational structure all have a positive impact on insurers' insolvency, but the growth and size of the company factors are not statistically significant.

The studies (Shiu, 2005) and (Caporale et al., 2017) share that both studies analyzed macroeconomic factors and special factors affecting the solvency of insurance companies, both studies agreed that leverage had a negative impact on the solvency of insurance companies, while the results of the two studies differed in the impact of the size of the company on solvency. The study (Shiu, 2005) showed a negative impact, but according to (Caporale et al., 2017) the effect was not statistically significant.

In the study (Yakob, et al., 2012), which addressed the factors affecting the solvency of insurance companies in Malaysia, corporate factors were taken into account, using the regression of random effects of panel data for 2003-2007. The study was concluded that leverage, liquidity, the ratio of total interest paid to fixed capital, and surplus ratio have a negative and statistically significant impact on the solvency of insurance companies in Malaysia. These results are consistent with (Caporale et al., 2017), which concluded that both liquidity and leverage hurt the solvency of insurance companies and are in line with the results of the (Shiu,2005) study, which concluded that leverage has a negative impact on solvency.

In (Hsiao and Whang, 2009) to assess the financial situation and monitor the solvency of selected samples in Taiwan, the study examined several factors to study solvency: capital equity, assets, profitability, liquidity, management, market sensitivity. The study found that all the previous factors have a positive and statistically significant impact on the solvency of insurance companies in Taiwan. This result differs from the result of a study (Yakob, et al., 2012) which concluded that liquidity has a negative impact on the solvency of insurance companies.

At the level of the European Union, (Carson and Hoyt, 2000) have been examined to identify important variables in early detection of the financial distress of life insurance companies, and study the importance of these variables in assessing the risk of insolvency of insurance companies. The study sample included 1900 insurance companies, covering the period 1984-2000, using the logistic regression model, the results showed that capital and surplus had a negative impact on insurers' insolvency, in addition, the concentration of the insurance company's work in specific geographic areas has a negative impact on its insolvency, because it gives it a competitive advantage over other insurance companies, and a positive effect for liabilities to current assets, leverage, and ratio of real estate to total assets on the insolvency of life insurance companies in the European Union.

This result of study (Carson and Hoyt, 2000) is consistent with (Hsiao and Whang, 2009) and (Shiu, 2005) which found that capital has a positive impact on the solvency of insurance companies, and compatible with the result of the study (Yakob, et al., 2012), and (Caporale, et al., 2017) which found that the financial leverage has a negative impact on the solvency of insurance companies. 
In study (Komen, 2012), the objective was to determine the determinants of the solvency of insurance companies in Kenya from 2001 to 2010, by using the multiple regression analysis, the impact of liquidity, ratio of claims, investments, growth in premiums, and size of the company on the solvency of insurance companies in Kenya was studied. The study found that both liquidity and surplus growth had a positive impact on the solvency of insurance companies in Kenya, while investment (ratio of investment income to premiums) and the ratio of claims had a negative impact on the solvency of insurance companies in Kenya, while the size of the company did not have a statistically significant impact.

In another similar study in Kenya (Mwargi and Murigu, 2015) to determine the factors affecting the profitability of insurance companies (Revenue to Assets Ratio), by using data from 2009-2012, and applying the multiple linear regression method. The study found that leverage, equity capital and management efficiency index had a positive impact on the profitability of insurance companies, while profitability was negatively correlated with the size of companies, liquidity, and ownership structure of insurance companies, while the retention ratio, underwriting risk, and age of the company did not affect the profitability of insurance companies.

In another study in Spain (Moreno, et al., 2018) to analyze the factors determining the solvency of insurance companies operating from 2008-2015, using a dynamic panel data model. The study found that actual solvency margins were positively correlated with profitability, underwriting risk, and mutual- type organization, and inversely with company size, reinsurance use, and life insurance specialization. While the study (Misas and Moreno, 2017) examined the factors affecting the regulatory solvency of insurance companies in Spain, where the study found that the growth in premiums and reinsurance has a negative impact on the regulatory solvency of insurance companies, while the investment risk, operational leverage, and size of the enterprise did not have a statistically significant impact. While the study (Rauch and Wende, 2015) in Germany, found that operating leverage has a negative impact on the regulatory solvency of insurance companies, while the investment risk had a positive impact

To analyze the determinants of financial performance in the Romanian's insurance market, a study (Burca and Batrinca, 2014) used a specific method of panel data, by using data from 2008-2012. It was concluded that the leverage and underwriting risks negatively affect the financial performance of insurance companies while the size of the institution, the solvency and the retained risk ratio have a positive impact on the financial performance of insurance companies.

From previous studies, and according to available data and the financial statements of the insurance companies in Palestine, we need to examine the effect of liquidity, investment, claims and leverage on the solvency of insurance companies in Palestine.

\section{Methodology and Data}

The method of descriptive and quantitative analysis was used in the study and the panel least squares method used in regression analysis where fixed effects coefficients were estimated.

After reviewing the literature of the study, and as provided by the insurance companies' data, the following econometric model was used to study the factors that affect the solvency of the insurance companies in Palestine.

$$
\text { Solvency }=\alpha_{0}+\alpha_{1} \text { Leverage }+\alpha_{2} \text { Investment }+\alpha_{3} \text { Liquidity }+\alpha_{4} \text { Claims ratio }
$$

The variables represent the following:

\begin{tabular}{ll}
\hline Solvency (Debt ratio) & The ability of a company to meet its long-term debts and financial obligations. \\
\hline Leverage & The amount of debt a firm uses to finance assets. \\
\hline Investment & $\begin{array}{l}\text { Investment income, defined as the placement of funds in projects to achieve the } \\
\text { return of the company. }\end{array}$ \\
\hline Liquidity & Reflect the Company's ability to meet its obligations when due. \\
\hline Claims ratio & $\begin{array}{l}\text { The proportion of claims, defined as the proportion of compensation losses that } \\
\text { occur to the insured. }\end{array}$ \\
\hline
\end{tabular}

Studies (Siu, 2005), (Caporale, et at., 2017), (Carson and Hoyt, 2000) and (Yakob, et al., 2012) emphasized the importance of leverage in the study of solvency, Calculated by dividing the total liabilities by the total equity. 
While the study (Komen, 2012) stressed the importance of studying the proportion of claims, as calculated by dividing the compensation paid on equity. The study also referred to the impact of investment on financial solvency, as investment was calculated by total income from non-insurance activity.

As for the liquidity variable, many studies (Hsiao and Whang, 2009), (Caporale, et at., 2017), and Yakob et al. (2012) indicate the importance of liquidity insolvency, where the liquidity ratio was calculated by the total current assets on the total current liabilities.

The study sample included seven insurance companies in Palestine out of 9 companies. Two companies do not provide study data and therefore are not included in the sample. The study relied on annual data from insurance companies' financial statements and annual reports published on the Palestine Stock Exchange website in 2010 To 2017.

\subsection{Description of Study Variables}

To achieve the objectives of the study, and to give a clearer picture of the variables of the study, the descriptive analysis of the solvency, investment, claims, leverage, and liquidity ratio of insurance companies in Palestine in the period from 2010 to 2017 is required. Table 1 gives a statistical description of the study variables.

Table 1. Statistical description of study variables

\begin{tabular}{llllll}
\hline & LIQUIDITY & LEVERAGE & DEPT_RATI & INVESTMENT & CLAIMS_RATI \\
\hline Mean & 1.030614 & 2.872706 & 0.717070 & 5.373894 & 1.343008 \\
\hline Median & 0.878850 & 2.218748 & 0.701744 & 5.464434 & 0.695876 \\
\hline Maximum & 7.867635 & 44.18537 & 1.191740 & 7.340583 & 16.50718 \\
\hline Minimum & 0.368526 & -21.46735 & 0.450111 & 3.078819 & -2.340420 \\
\hline Std. Dev. & 0.964269 & 7.512705 & 0.131948 & 1.137943 & 3.367283 \\
\hline Skewness & 6.514043 & 2.164504 & 1.046433 & -0.206879 & 2.977137 \\
\hline Kurtosis & 46.80737 & 20.48142 & 5.409984 & 2.147883 & 11.83179
\end{tabular}

The table was calculated by the researcher using the E-views program, based on the financial statements of insurance companies in Palestine.

Table 1 shows that the average solvency ratio (the ratio of total liabilities to total assets) for insurance companies in Palestine is $71.7 \%$, i.e., liabilities constitute about $0.7 \%$ of total assets of insurance companies.

While the average liquidity (ratio of liquid assets to total assets) in the insurance companies is $103 \%$, that is, the insurance companies have more liquidity than the fixed assets. This percentage can be understood that the insurance companies can pay their obligations, Insurers' weakness in investment in fixed assets.

The table shows that the average leverage (total claims to total equity) of insurance companies is $287 \%$, meaning that insurers' credit for financing their investments is more than twice their total equity.

However, the average investment income (revenues from non-insurance activity) for insurance companies is $537 \%$. This indicates that insurance companies in Palestine rely heavily on income from investments rather than income from the insurance business.

While the percentage of claims (compensation paid to equity) for insurance companies is $134 \%$, this indicates that on average the compensation paid by the insurance companies is greater than the property rights. However, table (1) shows a variance in data, where there is a significant difference in data between each insurance company. To illustrate the change in the rate of study variables from 2010 to 2017, Figure 1 illustrates this. 

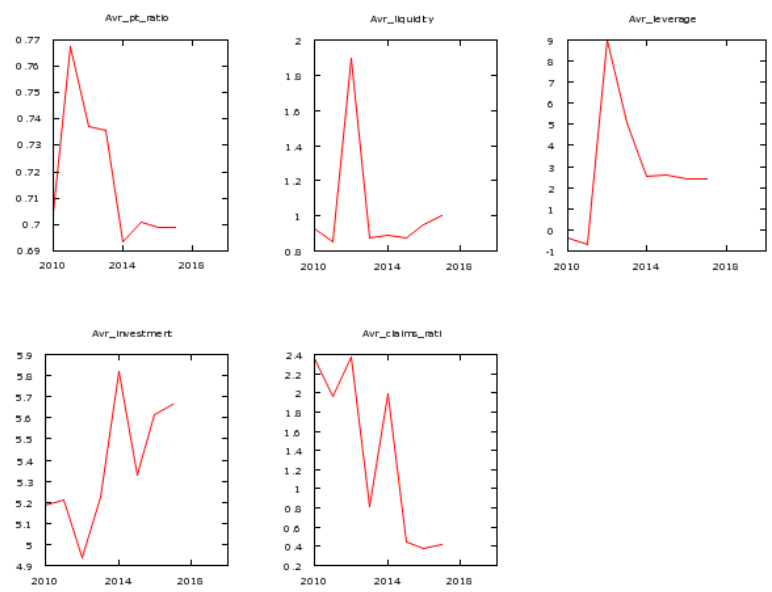

Figure 1. The average of study variables during the period 2010-2017

The Figure was done by the researcher using the Gretl program.

Figure 1 shows that the solvency rate of the insurance companies in Palestine has increased sharply since the beginning of 2010 to 2012 and then decreased significantly until reaching its lowest point in 2014 to reach 0.69 .

While the liquidity and leverage ratio starts to decline by the beginning of 2010 and then began to rise dramatically to reach their highest levels in 2013, after that, decline sharply by the beginning of 2014 and continue the same proportion until 2017.

As for the investment rate of the insurance companies in Palestine, the figure shows that it is highly volatile, with the investment rate reaching the lowest rate for 2012, and then rising to the highest rate in 2014.

While the rate of claims was at its highest rate in 2010, then began to decline and rise until it reached its lowest rate in 2017.

\section{Analysis}

In this section, we will review the relationship between the variables of the study, the normal distribution of the data, and the results of the regression analysis using the panel least squares method.

To illustrate the correlations between the dependent variable and the independent variables on the one hand, and the independent variables on the other, to understand the study variables more. Table 2 presents these correlations.

Table 2. Correlations between study variables

\begin{tabular}{|c|c|c|c|c|c|c|}
\hline & & $\begin{array}{l}\text { Dept_Ratio_ } \\
\text { Solvancy }\end{array}$ & Liquidity & Leverage & Investment & $\begin{array}{c}\text { Claims } \\
\text { ratio }\end{array}$ \\
\hline \multirow{3}{*}{$\begin{array}{l}\text { Dept_Ratio } \\
\text { _Solvancy }\end{array}$} & Pearson correlation & 1 & -0.236 & 0.041 & -0.526 & 0.563 \\
\hline & Sig. (2-tailed) & & 0.080 & 0.763 & 0.000 & 0.000 \\
\hline & $\mathrm{N}$ & 56 & 56 & 56 & 56 & 56 \\
\hline \multirow[t]{3}{*}{ Liquidity } & Pearson correlation & -0.236 & 1 & -0.028 & 0.155 & -0.112 \\
\hline & Sig.(2-tailed) & 0.080 & & 0.839 & 0.254 & 0.411 \\
\hline & $\mathrm{N}$ & 56 & 56 & 56 & 56 & 56 \\
\hline \multirow[t]{3}{*}{ Leverage } & Pearson correlation & 0.041 & -0.028 & 1 & -0.085 & 0.165 \\
\hline & Sig.(2-tailed) & 0.763 & 0.839 & & 0.534 & 0.224 \\
\hline & $\mathrm{N}$ & 56 & 56 & 56 & 56 & 56 \\
\hline \multirow[t]{3}{*}{ Investment } & Pearson correlation & -0.526 & 0.155 & -0.085 & 1 & -0.296 \\
\hline & Sig.(2-tailed) & 0.000 & 0.254 & 0.534 & & 0.027 \\
\hline & $\mathrm{N}$ & 56 & 56 & 56 & 56 & 56 \\
\hline \multirow{3}{*}{$\begin{array}{l}\text { Claims_rati } \\
0\end{array}$} & Pearson correlation & 0.563 & -0.112 & 0.165 & -0.296 & 1 \\
\hline & Sig.(2-tailed) & 0.000 & 0.411 & 0.224 & 0.027 & \\
\hline & $\mathrm{N}$ & 56 & 56 & 56 & 56 & 56 \\
\hline
\end{tabular}


This table was calculated by the researcher using the SPSS program, based on the financial statements of insurance companies in Palestine.

Table 2 shows that solvency is positively correlated with the ratio of claims and leverage, while negatively correlated with liquidity and investment, while liquidity is negatively correlated with the leverage and claims ratio, the leverage is also negatively correlated with investment, and positively with the proportion of claims. It is noted that the correlation between solvency and both liquidity and the proportion of claims are statistically significant, as well as the correlation between investment and the proportion of claims of statistical significance. And to ensure the normal distribution of data before regression analysis, to ensure the efficiency of regression coefficients.

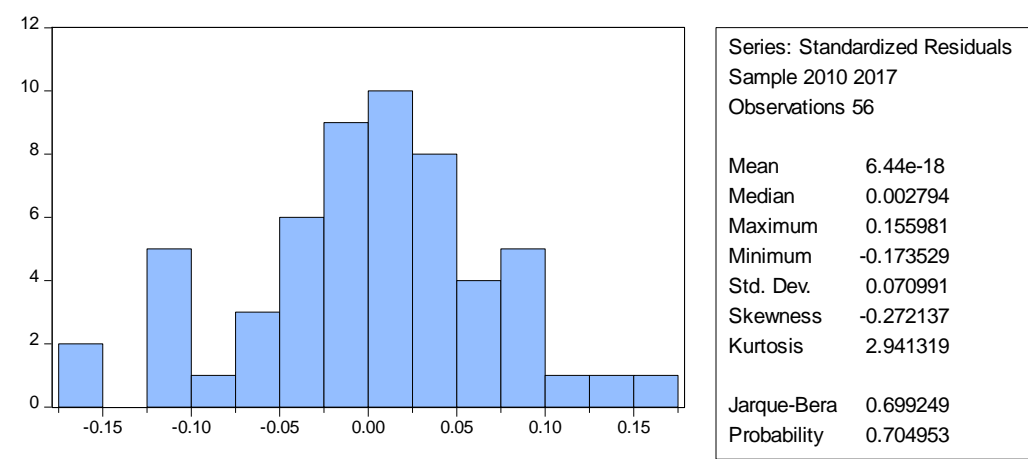

Figure 2. Normal distribution of the study variables

The Figure was done by the researcher using E-views 10 program

Figure 2 appears that the data distribution takes the shape of the bell since (Probability $=0.7049>\alpha=0.05$ ) therefore, the data were normally distribution.

To achieve the objectives of the study, the multiple regression model was used, and to estimate the coefficients of study, the panel least squares method applied, Where the coefficients were estimated using fixed effects and random effects. The results of Hausmann test are rejected for random effects, and therefore are considered inconsistent and it will not be analyzed. And the Table 3 shows the results of regression analysis.

Table 3. Results of regression analysis

\begin{tabular}{|c|c|c|c|c|}
\hline \multicolumn{5}{|c|}{ Dependent Variable: DEPT_RATIO_SOLVANCY } \\
\hline \multicolumn{5}{|c|}{ Method: Panel least squares } \\
\hline \multicolumn{5}{|l|}{ Sample: 20102017} \\
\hline \multicolumn{5}{|c|}{ The period included: 8} \\
\hline \multicolumn{5}{|c|}{ Cross-sectionss included: 7} \\
\hline \multicolumn{5}{|c|}{ Total panel (balanced) observations: 56} \\
\hline Variable & Coefficient & Std. Error & t-Statistic & Prob. \\
\hline $\mathrm{C}$ & 0.831832 & 0.115180 & 7.222039 & 0.0000 \\
\hline INVESTMENT & -0.023326 & 0.021715 & -1.074165 & 0.2895 \\
\hline LEVERAGE & -0.002936 & 0.001743 & -1.683962 & 0.1000 \\
\hline LIQUIDITY & -0.004651 & 0.014174 & -0.328163 & 0.7446 \\
\hline CLAIMS_RATIO & 0.017734 & 0.005586 & 3.174636 & 0.0030 \\
\hline
\end{tabular}


Cross-section fixed (dummy variables)

The period fixed (dummy variables)

\begin{tabular}{llll}
\hline R-squared & 0.710531 & Mean dependent var & 0.717070 \\
\hline Adjusted R-square & 0.581032 & S.D dependent & 0.131948 \\
\hline S.E of regression & 0.085407 & Akaike info criterion & -1.827688 \\
\hline Sum squared resid & 0.277185 & Schwarz criterion & -1.176682 \\
\hline Log-likelihood & 69.17525 & Hannan-Quinn criteria. & -1.575294 \\
\hline F-statistic & 5.486759 & Durbin- Watson stat & 0.984568 \\
\hline Prob(F-statistic) & 0.000007 & & \\
\hline
\end{tabular}

The table was calculated by the researcher using the E-views10 program, based on the financial statements of insurance companies in Palestine.

Table 3 shows that $\mathrm{R}^{2}=71 \%$, which means that the independent variables in the model explained $71 \%$ of the change insolvency, and the results show that the model is statistically significant because Prob (F-statistic) $=0.000<\alpha=0.05$.

It appears that when the leverage is increased by $1 \%$, the solvency will be reduced by $0.3 \%$. This relationship is statistically significant when $\alpha=0.10$, this is because when the leverage is increased, the insurance company is more leveraged to perform its obligations, which reduces the solvency of these companies.

While solvency rises by $1.7 \%$ when the claims ratio increases by $1 \%$ and this relationship is statistically significant at $\alpha=0.05$. While the relationship between liquidity and solvency is negative, but not statistically significant. Also, the relationship between investment and financial solvency is negative and not statistically significant.

\section{Discussion and Conclusions}

The study examined the effect of leverage, liquidity, and investment on the solvency of insurance companies in Palestine. The study concluded that leverage has a negative impact on solvency. When leverage increases by $1 \%$, the solvency will decrease by $0.3 \%$. The result corresponds to the results of studies (Shiu, 2005), (Caporale, et.al., 2017), (Carson and Hoyt, 2000) and (Yakob, et.al., 2012), which concluded that the financial leverage has a negative and statistically significant impact on the solvency of the insurance companies. This is because the leverage means increasing the company's financing to meet its needs whether by borrowing or bonds, thus, the solvency ratio, which is the ratio of total liabilities to total assets, will be reduced. While according to (Rauch and Wende, 2015), operational leverage had a negative impact on regulatory solvency in insurance companies, while according (Mwargi and Murigu, 2015) operational leverage had no statistically significant effect on regulatory solvency in insurance companies.

The results show that the ratio of claims has a positive impact on solvency. When the ratio of claims increases by $1 \%$, solvency will increase by $1.7 \%$. This result is inconsistent with the result of the (Komen, 2012) study, which found that the claim ratio has a negative impact on the solvency of insurance companies. Here, the positive effect of the ratio of claims on solvency in our study can be justified by the increase in the proportion of claims paid to equity, it will increase total liabilities to total assets, and thus increase the solvency of insurance companies.

The study found that the relationship between liquidity and solvency is negative but not statistically significant. This finding is consistent with the results of previous studies. Where studies (Caporale, et.al., 2017 ), (Yakob, et.al., 2012), (Hsiao and Whang, 2009) and (Komen, 2012) indicate that the liquidity has a negative but statistically significant impact on the solvency of insurance companies. According to the study (Mwargi and Murigu, 2015), liquidity has a negative impact on the profitability of insurance companies, where the liquidity considered the most important financial matters in the company, which reflects the ability of the company to meet its obligations.

According to the results, investment has a negative impact on solvency, but this effect is not statistically significant. This is consistent with the study of (Komen, 2012), this can be explained by the investing money increased, the return of the insurance company will increase, and they become more able to meet their obligations in their history or when they are due. While according (Rauch and Wende, 2015), investment risk has a positive impact on the regulatory solvency of insurance companies, while investment risk did not have a statistically significant impact on the regulatory solvency of insurance companies (Misas and Moreno, 2017). 
The study recommends that companies should be encouraged to invest their liquidity, increase investment and raise the capital of the company to reduce leverage. Also, the study suggests further research on the subject and research on the impact of macroeconomic factors on the solvency of insurance companies, and examine the impact of further factors, such as growth in premiums, reinsurance use, size of the enterprise, and capital.

\section{Acknowledgement}

Authors acknowledge Palestine Technical University for funding the current study.

\section{References}

Affolter, I. (2009). Solvency Regulation and Contract Pricing in the Insurance Industry. Dissertation no 3601 Difo-Druck GmbH, Bamberg. $\quad$ Retrieved from https://www1.unisg.ch/www/edis.nsf/SysLkpByIdentifier/3601/\$FILE/dis3601.pdf

Burca, A., \& Batrinca, G. (2014). The determinants of financial performance in the Romanian insurance market. International Journal of Academic Research in Accounting Finance and Management Science, 4(1), 299-308. https://doi.org/10.6007/IJARAFMS/v4-i1/637

Caporale, G., Cerrato, M., \& Zhang, X. (2017). Analyzing the determinants of insolvency risk for general insurance firms in the UK. Journal of banking and Finance, 84, 107-122. https://doi.org/10.1016/j.jbankfin.2017.07.011

Carson, J., \& Hoyt, R. (2000). Evaluating the risk of life insurer insolvency: implications from the US for the European Union. Journal of Multinational Financial Management, 10, 297-314. https://doi.org/10.1016/S1042-444X(00)00023-2

Daykin, C., Devitt, E., Khan, M., \& McCaughan, J. (1984). The solvency of general insurance companies. Journal of the Institute of Actuaries, 111(2), 279-336. https://doi.org/10.1017/S0020268100041718

Hsiao, S., \& Whang, T. (2009). A study of a financial insolvency prediction model for life insurers. Expert Systems With Applications, 36, 6100-6107. https://doi.org/10.1016/j.eswa.2008.07.024

Jacobs, J. (2013). Lessons Learnt from the Deficiencies of the Basel Accords as they Apply to Solvency II. Doctoral dissertation, $\quad$ North-West University. $\quad$ Retrieved from https://repository.nwu.ac.za/bitstream/handle/10394/11726/Jacobs_JRG.pdf?sequence=1

Komen, D. (2012). Determinants of solvency margins of insurance companies in Kenya. University of Nairobi. Retrieved from http://erepository.uonbi.ac.ke/handle/11295/13218

Misas, M., \& Moreno, M. (2017). Solvency surveillance and financial crisis: evidence from the Spanish insurance industry. Journal of Finance and Accounting, 272-297. https://doi.org/10.1080/02102412.2017.1291167

Moreno, I., Martinez, P., \& Ponce, A. (2018). Economic crisis and determinants of solvency in the insurance sector: new evidence from Spain. Accounting and Finance. https://doi.org/10.1111/acfi.12422

Mwangi, M., \& Murigu, J. (2015). The determinants of financial performance in General insurance companies in Kenya. European Scientific Journal, 11(1).

Palestine Capital Market Authority (PCMA). (2018). Insurance sector overview. Retrieved from http://www.mas.ps/arabic.php

Palestine Economic Policy Research Institute-MAS. (2016). The reality of the insurance sector in Palestine. Achievements -Failures - Challenges. Retrieved from http://www.mas.ps/files/server/20162502101522-2.pdf

Pearson, R. (2015). The development of international insurance. Routledge. Retrieved from https://books.google.ps/books/about/The_Development_of_International_Insuran.html?id=8r06CgAAQBAJ\&re dir_esc $=$ y

Rauch, J., \& Wende, S. (2015). Solvency prediction for property- liability insurance companies: Evidence from the financial crisis. The Geneva Papers, 40, 47-65. https://doi.org/10.1057/gpp.2014.16

Shiu, Y. (2005). The determinants of solvency in the United Kingdom's life insurance market. Applied Economics Letters, 12(6), 339-334. https://doi.org/10.1080/13504850500092640

Yakob, R., Yusop, Z., Radam, A., \& Ismail, N. (2012). Solvency determinants of conventional life insurers and Takaful operators. Asia-Pacific Journal of Risk and Insurance, 6(2). https://doi.org/10.1515/2153-3792.1143 